\title{
Effect of Korean red ginseng extract on liver damage induced by short- term and long-term ethanol treatment in rats
}

\author{
Su-Jeong Seo ${ }^{1}$, Jae Youl $\mathrm{Cho}^{2}$, Yeon Ho Jeong ${ }^{1,3}$, and Yong-Soon Choi ${ }^{1,3^{*}}$ \\ ${ }^{1}$ Department of Medical Biotechnology, College of Medical Biosciences, Kangwon National University, Chuncheon 200-701, \\ Korea \\ ${ }^{2}$ Department of Genetic Engineering, Sungkyunkwan University, Suwon 440-746, Korea \\ ${ }^{3}$ Institute of Bioscience and Biotechnology, Kangwon National University, Chuncheon 200-701, Korea
}

Edited by Jong-Hoon Kim, Chonbuk National University, Korea

Korean red ginseng (KRG) is prepared by the process of steaming the roots of Panax ginseng. In this study, the feeding effects of KRG-water extract (KRGE) on ethanol-induced liver damage were elucidated by measuring serum biomarkers in rats. Serum $\gamma$-glutamyltranspeptidase $(\gamma$-GT) activity and the concentration of malondialdehyde (MDA) were significantly increased by shortterm and long-term ethanol treatment in rats, whereas the activities of serum glutamate pyruvate transaminase (GPT) and glutamate oxaloacetate transaminase (GOT) did not respond. Pretreatment with KRGE maintained the activity of serum GPT, and the MDA concentration induced by short-term ethanol ingestion remained within the normal range. However, co-feeding of KRGE to rats decreased the concentration of MDA but failed to modulate the serum $\gamma$-GT activity induced by long-term ethanol treatment. Our studies suggest that in rats, it appears that KRGE does not sufficiently reverse the physiological response evoked by long-term ethanol ingestion to maintain normal conditions, in view of the serum biomarker $\gamma$-GT, regardless of KRGE's favorable antioxidant activity.

Keywords: Panax ginseng, Korean red ginseng extract, Ethanol, Malondialdehyde, Serum $\gamma$-glutamyltranspeptidase

\section{INTRODUCTION}

Panax ginseng has been used as a traditional herbal medicine for over 2,000 years in Korea and other Asian countries, and has been shown to exert pharmacological and physiological effects in humans as well as animals $[1,2]$. Depending on the processing of raw ginseng, ginseng can be largely classified into two types, white ginseng dried by air and red ginseng treated by steaming. Korean red ginseng (KRG) has been reported to have more effective pharmacological activities than white or raw ginseng [3-6].

Over time, alcohol consumption has increased all over

(c) This is an Open Access article distributed under the terms of the Creative Commons Attribution Non-Commercial License (http://creativecommons.org/licenses/by-nc/3.0/) which permits unrestricted non-commercial use, distribution, and reproduction in any medium, provided the original work is properly cited. the world and has evoked a variety of health problems in relation to functional lesions in the liver [7,8]. The liver is the main metabolic organ for ingested alcohol; therefore, the series of events that occur in the liver following alcohol intake may predispose the organ to damage. Thus, biochemical markers in the liver and serum have been widely used as effective methods for the early diagnosis of liver diseases and to determine the functional components for prevention or treatment of hepatic lesions or chronic alcoholism [7,9-12].

Nevertheless, most of the reported studies on the ef-

Received 05 Oct. 2012, Revised 26 Nov. 2012, Accepted 26 Nov. 2012

*Corresponding author

E-mail: yschoi@kangwon.ac.kr

Tel: +82-33-250-6482, Fax: +82-33-241-6480 
fects of ginseng or red ginseng related to liver function have used animals with damage induced by drugs [13]. Available data are limited on the biochemical or physiological effects of red ginseng in animals or humans treated with ethanol $[14,15]$.

Here, we tried to evaluate the effects of KRG-water extract (KRGE) on liver function in rats treated with ethanol for short-term or long-term periods by analyzing biochemical parameters, because ethanol is a representative and troublesome chemical to which humans are exposed in our society $[11,16]$.

\section{MATERIALS AND METHODS}

\section{Sample preparation}

KRGE derived from the root of $P$. ginseng was provided from the Korea Ginseng Corporation (Seoul, Korea). KRGE is made through a secondary process that concentrates the water extract of six-year-old KRG roots, and it was dissolved directly in 5\% diluted ethanol, (1.0\% as final concentration). The general composition of the product offered by the Korea Ginseng Corporation is as follows: moisture $36 \%$, solid volume $64 \%$, ash $2.5 \%$, total fat $0.05 \%$, total crude saponin $70 \mathrm{mg} / \mathrm{g}$, and total ginsenosides $20 \mathrm{mg} / \mathrm{g}$.

\section{Short-term ethanol ingestion}

Five-week-old male, specific-pathogen-free SpragueDawley rats were purchased from Japan SLC (Shizoka, Japan) and used as an experimental animal model. Preclinical and clinical studies have indicated that ovarian hormones, particularly estrogen, play a role in producing sex differences in drug abuse [17]; therefore, we used only male rats as a model. Rats were adapted to solid feed for one week. Rats were divided into three groups of six rats each, designated as 1) normal diet group (NORMAL), 2) ethanol-fed group (ETHANOL), and 3) ethanol plus $10 \mathrm{~g} / \mathrm{L}$ KRGE (KRGE). The normal and ethanol groups had free access to $0.2 \mathrm{~g} / \mathrm{L}$ sucrose solution, while the KRGE group was given a $10 \mathrm{~g} / \mathrm{L}$ solution of KRGE. The $10 \mathrm{~g} / \mathrm{L}$ solution of KRGE has a reduced sugar content equivalent to $0.2 \mathrm{~g} / \mathrm{L}$ sucrose.

Rats were fed commercial AIN 93G diets [18] as pellets (Dyets Inc., Bethlehem, PA, USA) freely for $2 \mathrm{wk}$. Rats were housed individually in a temperature-controlled room $\left(23^{\circ} \mathrm{C}\right.$ to $\left.25^{\circ} \mathrm{C}\right)$ with a $12 / 12 \mathrm{~h} \mathrm{light/dark} \mathrm{cycle.} \mathrm{Af-}$ ter $2 \mathrm{wk}$, the rats were fasted for $6 \mathrm{~h}$. The control group was given saline, and the ethanol and KRGE groups were given $3.5 \mathrm{~g}$ of ethanol $/ \mathrm{kg}$ body weight in an aqueous $35 \%$ solution via gastric tube [19]. All animals fasted for $17 \mathrm{~h}$
Table 1. The composition of experimental diets in long-term ethanol-treated rats $(\mathrm{g} / \mathrm{L})^{1)}$

\begin{tabular}{|c|c|c|c|}
\hline \multirow{2}{*}{ Ingredients } & \multirow{2}{*}{ NORMAL } & \multicolumn{2}{|c|}{ Experimental diets } \\
\hline & & ETHANOL & KRGE \\
\hline Dextrin-maltose & 153.00 & 64.00 & 64.00 \\
\hline Casein & 41.40 & 41.40 & 41.40 \\
\hline Olive oil & 15.00 & 15.00 & 15.00 \\
\hline Fiber (cellulose) & 10.00 & 10.00 & 10.00 \\
\hline Mineral mix (AIN-93) & 9.00 & 9.00 & 9.00 \\
\hline Corn oil & 8.00 & 8.00 & 8.00 \\
\hline Xanthan gum & 3.00 & 3.00 & 3.00 \\
\hline Vitamin mix (AIN-93) & 2.55 & 2.55 & 2.55 \\
\hline Choline bitartrate & 0.53 & 0.53 & 0.53 \\
\hline L-cystine & 0.50 & 0.50 & 0.50 \\
\hline DL-methionine & 0.30 & 0.30 & 0.30 \\
\hline Ethanol (50 v/v\%) & - & 100 & 50 \\
\hline $\mathrm{KRGE}^{2)}$ & - & - & 500 \\
\hline
\end{tabular}

NORMAL, normal diet group; ETHANOL, ethanol-fed group; KRGE, ethanol plus $10 \mathrm{~g} / \mathrm{L}$ Korean red ginseng extract.

${ }^{1)}$ Finally, distilled water was added to make the total volume $1 \mathrm{~L}$ each. ${ }^{2)} \mathrm{KRGE}(10 \mathrm{~g})$ was diluted with $500 \mathrm{~mL}$ of $5.0 \mathrm{v} / \mathrm{v} \%$ ethanol.

after ingestion of saline or alcohol before decapitation.

\section{Long-term ethanol ingestion}

Five-week-old male, specific-pathogen-free SpragueDawley rats that were purchased from Japan SLC were acclimated to standard chow for one week and then divided into three groups of six rats each, designated as normal (NORMAL), ethanol (ETHANOL), and ethanol plus KRGE (KRGE). The experimental diet was prepared according to the Lieber-Decarli rat liquid diet method [20] and prepared fresh every day prior to use. Table 1 shows the composition of the diets. For the KRGE group, the final concentration of red ginseng extract was adjusted to $10 \mathrm{~g} / \mathrm{L}$ of the liquid diet. Previously, Kwak et al. [21] elucidated the effect of $1,000 \mathrm{mg} / \mathrm{kg}$ of red ginseng acidic polysaccharide, equivalent to $2,000 \mathrm{mg} / \mathrm{kg}$ of KRGE in rats, showing a significant hypolipidemic effect. In this study, therefore, the doses of KRGE (350 to $1,700 \mathrm{mg}$ / $\mathrm{kg}$ depending on drinking volume) seem to be within an acceptable range for the rat model.

Rats were housed individually in a temperaturecontrolled room $\left(23^{\circ} \mathrm{C}\right.$ to $\left.25^{\circ} \mathrm{C}\right)$ with a $12 / 12 \mathrm{~h}$ light/dark cycle. They had free access to food and water throughout the experimental period. Food intake and body weight were measured every $2 \mathrm{~d}$. After $6 \mathrm{wk}$ of being fed the experimental diets, rats were fasted for $12 \mathrm{~h}$ and then decapitated. 
Table 2. Relative liver weight and triacylglycerol level in short-term ethanol-treated rats

\begin{tabular}{cccc}
\hline \multirow{2}{*}{$\begin{array}{c}\text { mg/100 } \\
\text { bodyweight }\end{array}$} & NORMAL & \multicolumn{2}{c}{ Experimental diets } \\
\cline { 3 - 4 } & & ETHANOL & \multicolumn{1}{c}{ KRGE } \\
\hline Relative liver weight & $8.46 \pm 0.362$ & $8.11 \pm 0.448$ & $7.90 \pm 0.413$ \\
Liver triacylglycerol & $240.6 \pm 40.6^{\mathrm{a}}$ & $161.8 \pm 48.3^{\mathrm{a}, \mathrm{b}}$ & $123.0 \pm 18.6^{\mathrm{b}}$ \\
\hline
\end{tabular}

Mean \pm SE of 6 rats.

NORMAL, normal diet group; ETHANOL, ethanol-fed group; KRGE, ethanol plus $10 \mathrm{~g} / \mathrm{L}$ Korean red ginseng extract.

${ }^{\mathrm{a}, \mathrm{b}}$ means in the same line without a common letter differ at $p<0.05$
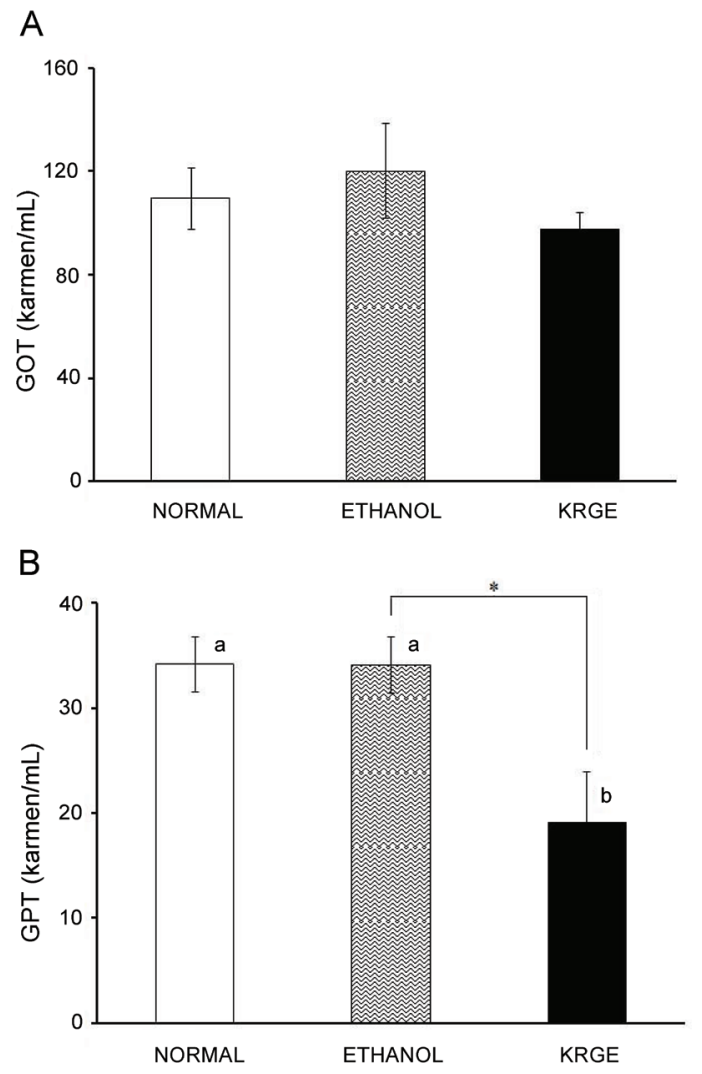

Fig. 1. The activities of serum glutamate oxaloacetate transaminase (GOT) (A) and glutamate pyruvate transaminase (GPT) (B) in short-term ethanol-treated rats. Mean \pm SE of 6 rats. NORMAL, normal diet group; ETHANOL, ethanol-fed group; KRGE, ethanol plus $10 \mathrm{~g} / \mathrm{L}$ Korean red ginseng extract. ${ }^{\mathrm{a}, \mathrm{b}}$ means without a common letter differ at $p<0.05$. "Significantly different from the corresponding values at $p<0.05$.

\section{Analytical methods}

Livers were excised, washed, and stored at $-70^{\circ} \mathrm{C}$ until analysis. Blood samples were collected in sterile test tubes and centrifuged at $1,500 \times \mathrm{g}$ for $15 \mathrm{~min}$ to obtain serum samples. Serum glutamate oxaloacetate transaminase (GOT) and glutamate pyruvate transaminase (GPT) activities were measured using commercially available kits (AM-101K; Asan Pharm., Seoul, Korea). Serum $\gamma$ glutamyltranspeptidase $(\gamma-\mathrm{GT})$ activity was also measured
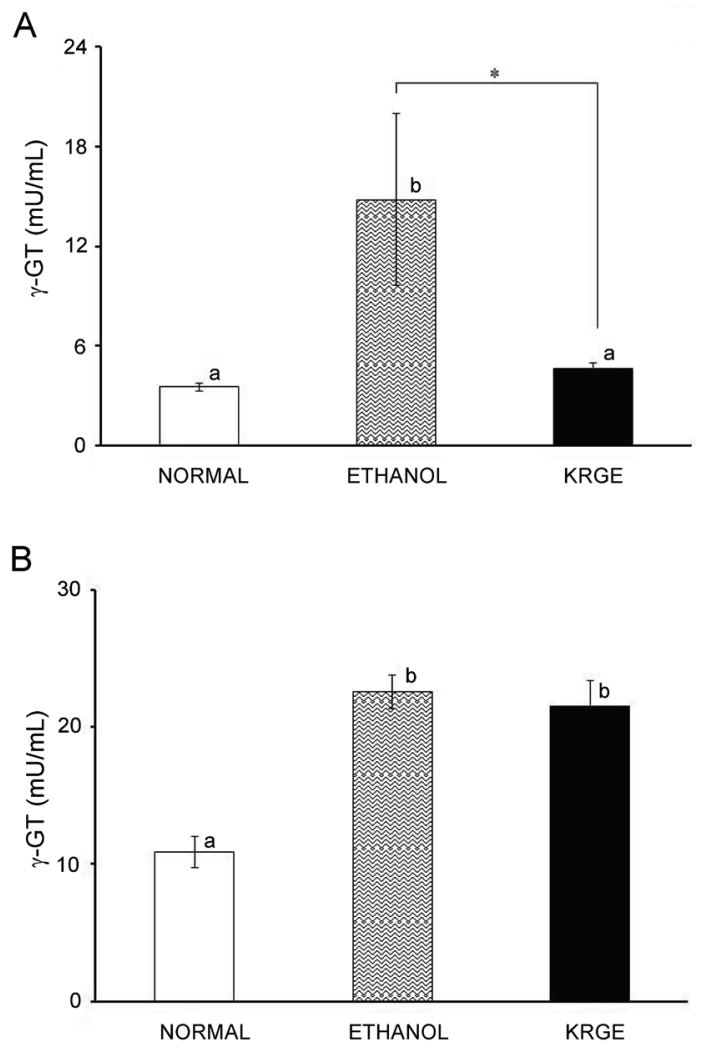

Fig. 2. The activities of serum $\gamma$-glutamyltranspeptidase $(\gamma-G T)$ in short-term (A) and long-term (B) ethanol-treated rats. Mean \pm SE of 6 rats. NORMAL, normal diet group; ETHANOL, ethanol-fed group; $\mathrm{KRGE}$, ethanol plus $10 \mathrm{~g} / \mathrm{L}$ Korean red ginseng extract. ${ }^{\mathrm{a}, \mathrm{b}}$ means without a common letter differ at $p<0.05$. "Significantly different from the corresponding values at $p<0.05$.

using a commercially available kit (AM-158K, Asan Pharm.). Liver and serum lipid malondialdehydes (MDA) were determined using the method described by Yagi [22]. Liver lipids were extracted and purified using the method of Folch et al. [23]. Liver lipid extracts were dissolved in acetone containing Triton X-100 [24], and then liver triacylglycerol levels were determined as described above.

\section{Data analysis}

Values are presented as the mean \pm SEM. Comparisons between groups were made using one-way analysis of variance. Differences between means were assessed by the least significant difference method when the $\mathrm{F}$ value was significant $(p<0.05)$ [25]. In some cases, significant differences $(p<0.05)$ between the ETHANOL and KRGE groups are indicated by an asterisk.

\section{RESULTS}

\section{Short-term ethanol treatment}

There were no significant differences in growth param- 
Table 3. Food intake, growth parameters, and liver triacylglycerol in long-term ethanol-treated rats

\begin{tabular}{lccc}
\hline & NORMAL & \multicolumn{2}{c}{ Experimental diets } \\
\cline { 3 - 4 } & & ETHANOL & KRGE \\
\hline Food intake $(\mathrm{mL} / \mathrm{d})$ & $104 \pm 2.2^{\mathrm{a}}$ & $74.0 \pm 0.92^{\mathrm{b}}$ & $86.5 \pm 3.39^{\mathrm{c}}$ \\
Weight gain $(\mathrm{g} / 6 \mathrm{wk})$ & $261 \pm 8.0^{\mathrm{a}}$ & $122 \pm 9.3^{\mathrm{b}}$ & $139 \pm 12.0^{\mathrm{c}}$ \\
$\begin{array}{c}\text { Relative liver weight } \\
\text { (g/100 g body weight) }\end{array}$ & $4.71 \pm 0.055^{\mathrm{a}}$ & $8.02 \pm 0.002^{\mathrm{b}}$ & $7.08 \pm 0.304^{\mathrm{b}}$ \\
$\begin{array}{c}\text { Liver triacylglycerol } \\
\text { (g/100 g body weight) }\end{array}$ & $92.0 \pm 11.9$ & $123.8 \pm 37.7$ & $103.0 \pm 22.0$ \\
\hline
\end{tabular}

Mean \pm SE of 6 rats.

NORMAL, normal diet group; ETHANOL, ethanol-fed group; KRGE, ethanol plus $10 \mathrm{~g} / \mathrm{L}$ Korean red ginseng extract.

${ }_{\text {a,b,c }}$ means in the same line without a common letter differ at $p<0.05$.

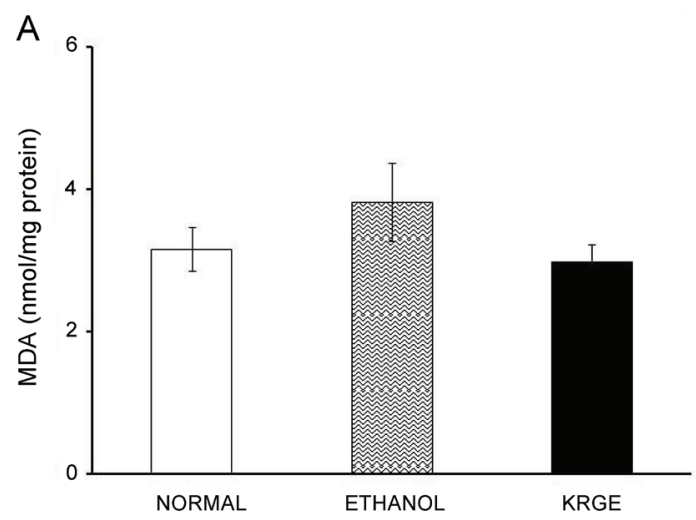

B

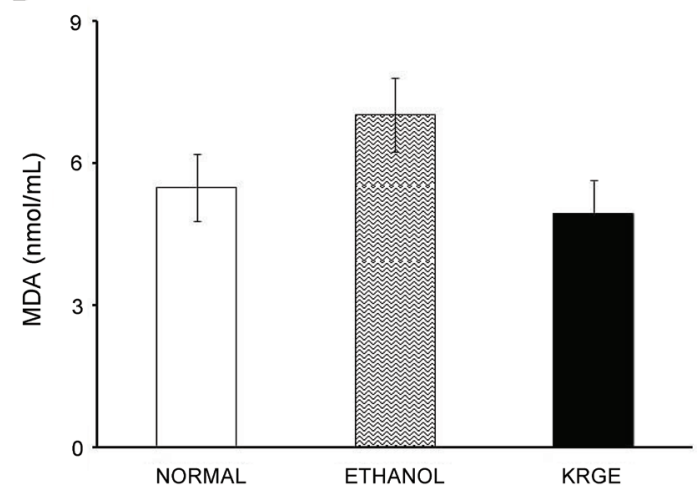

Fig. 3. The concentration of liver $(A)$ and serum malondialdehydes (MDA) (B) in short-term ethanol-treated rats. Mean \pm SE of 6 rats. NORMAL, normal diet group; ETHANOL, ethanol-fed group; KRGE, ethanol plus $10 \mathrm{~g} / \mathrm{L}$ Korean red ginseng extract.

eters, liver weight or food intake among the groups for 2 wk (data not shown). As shown in Table 2, short-term ethanol feeding significantly decreased the concentration of liver triacylglycerol; the concentration of liver triacylglycerol was highest in the NORMAL group and lowest in the KRGE group with the ETHANOL group being intermediate. Fig. 1 shows the activities of serum GOT and
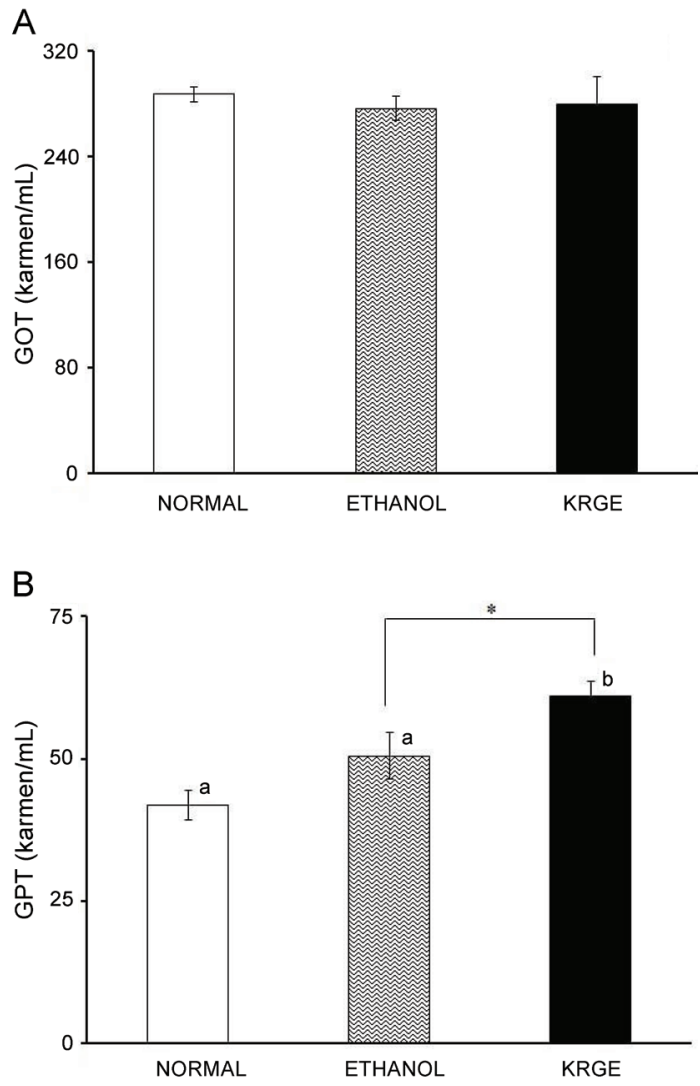

Fig. 4. The activities of serum glutamate oxaloacetate transaminase (GOT) (A) and glutamate pyruvate transaminase (GPT) (B) in long-term ethanol-treated rats. Mean $\pm S E$ of 6 rats. NORMAL, normal diet group; ETHANOL, ethanol-fed group; KRGE, ethanol plus $10 \mathrm{~g} /$ $L$ Korean red ginseng extract. ${ }^{a, b}$ means without a common letter differ at $p<0.05$. "Significantly different from the corresponding values at $p<0.05$.

GPT. Serum GOT and GPT activities were not affected by short-term ethanol ingestion. However, pretreatment with ginseng extract meaningfully reduced the activity of serum GPT. Fig. 2A shows the activity of serum $\gamma$-GT in short-term ethanol-treated rats; the activity was lowest in the KRGE group and highest in the ETHANOL group, while the NORMAL group was intermediate. Fig. 3 shows the concentration of MDA in the liver and serum of the rats. No significant differences were found in the liver and serum MDA concentrations due to ethanol or KRGE ingestion.

\section{Long-term ethanol treatment}

Table 3 shows the growth parameters, food intake, relative liver weights, and triacylglycerol values in rats chronically treated with ethanol. Ethanol feeding significantly reduced weight gain, irrespective of KRGE feeding. A similar pattern was observed in the food intake among the groups. Ethanol treatment increased relative 



Fig. 5. The concentration of liver $(A)$ and serum malondialdehydes (MDA) (B) in long-term ethanol-treated rats. Mean \pm SE of 6 rats. NORMAL, normal diet group; ETHANOL, ethanol-fed group; KRGE, ethanol plus $10 \mathrm{~g} / \mathrm{L}$ Korean red ginseng extract. ${ }^{\mathrm{a}, \mathrm{b}}$ means without a common letter differ at $p<0.05$. "Significantly different from the corresponding values at $p<0.05$.

liver weight and the concentration of liver triacylglycerol, whereas administration of KRGE did not affect liver weight change or liver triacylglycerol. Fig. 4 shows the activities of serum GOT and GPT. Ethanol did not affect the activities of GOT and GPT, whereas the activity of serum GPT was significantly increased by KRGE ingestion. Fig. 2B shows the activity of serum $\gamma$-GT. Ethanol treatment increased markedly the activity of serum $\gamma$-GT, but KRGE did not affect the elevated activity of serum $\gamma$-GT induced by long-term ethanol treatment. Fig. 5 shows the MDA concentrations in the liver and serum of the rats. Ethanol increased the concentration of MDA in the liver and serum; the concentration of MDA in the serum and liver was highest in the ETHANOL group and lowest in the KRGE group. The MDA-lowering effects of KRGE were markedly higher in the serum than in the liver.

\section{DISCUSSION}

It is well established that ethanol consumption pro- motes the formation of a variety of free radical products in the liver cells, which can lead to oxidative stress. Oxidative stress seems to be critically involved in liver damage during ethanol exposure and subsequently leads to liver disease [8-11]. Although increased levels of serum enzymes, such as GOT and GPT, have been observed in alcohol-treated rats, which indicate increased hepatic cell permeability, damage and/or necrosis of hepatocytes, observations of serum GOT and GPT induced by ethanol have been dependent on the animal strain, feeding period and method, and/or dosage of ethanol [10,26,27]. Nevertheless, it was evident that pretreatment with red ginseng may be effective in lowering the activity of serum GPT before drinking.

The induced concentration of serum $\gamma$-GT has been accepted as a biomarker of acute and chronic ethanol ingestion in animals and humans [27-30]. Hepatic and serum alterations in enzyme activity observed in patients with alcoholic fatty liver have been reproduced in the rat model of alcoholic fatty liver but only for $\gamma$-GT [31]; researchers have also shown that serum $\gamma$-GT activity is associated with increased hepatic $\gamma$-GT in rats that are chronically fed alcohol. Our present results, in which serum $\gamma$-GT activity was significantly induced by shortand long-term ethanol ingestion, are similar to previous findings $[27,30]$. Furthermore, our results demonstrate that pretreatment with KRGE could maintain the activity of serum $\gamma$-GT within the normal range, regardless of short-term ethanol ingestion.

An increase in the production of reactive oxygen species and enhancement of peroxidation of lipids, protein, and DNA by acute and chronic ethanol treatment has been demonstrated in various systems, cells, and animals, including humans [10,29,32]. Following ethanol ingestion, an increased serum MDA level might reflect enhanced peroxidation in the liver because peroxides formed in impaired liver cells can leak into the bloodstream, which is consistent with our present data.

The antioxidant capacity of red ginseng and its concentrates is well reported in in vitro experiments as well as in vivo animal and human studies [33,34]. In our studies, the antioxidant effect of KRGE was observed; liver and serum MDA levels were increased by short- and long-term ethanol ingestion, whereas red ginseng intake significantly decreased the MDA values, especially in long-term ethanol-treated rats. Our data indicate that red ginseng can effectively prevent and/or suppress the formation of lipid peroxides induced by ethanol treatment in rats.

It is known that short- and long-term alcohol feedings reduce hepatic glutathione contents in rats and humans; 
the depletion might be attributed to the free radical scavenging reactivity of glutathione and/or conjugates with acetaldehyde $[32,35]$. Thus, hepatic $\gamma$-GT seems to play an important role in supplying glutathione in the liver under ethanol detoxification conditions. Kera et al. [36] observed a rapid rise in the conjugating reaction between acetaldehyde and glutathione with the addition of $\gamma$-GT, suggesting a trapping of acetaldehyde by cysteinylglycine, the GSH metabolite. These data support the fact that an induction of serum $\gamma$-GT by ethanol might be an inevitable consequence, as observed in our present study.

Several studies [37,38] have demonstrated that ethanol ingestion evokes a reduction in intrahepatic content and the synthesis rate of glutathione and that quercetin and ellagic acid but not tocopherol restore the content of hepatic glutathione depleted by ethanol ingestion to normal status in animals. These results suggest that chemicals classified as antioxidants generally do not sufficiently compensate for the loss of glutathione caused by ethanol ingestion. In this respect, acetaldehydes that have escaped from the chronic ethanol oxidation pathway might activate hepatic $\gamma$-GT to produce its excretive metabolites. In contrast, the scavenging role of free radicals formed by ethanol can be replaced partly by antioxidants, such as the ginseng products used in the present study $[39,40]$.

Alternatively, our results suggest the possibility that KRGE may create an environment in which the availability of glutathione in the mitochondria is enhanced. Kim et al. [41] observed that ginseng saponin was evenly found within the inner membrane and matrix of mitochondria in rats, suggesting that some components of ginseng may directly influence mitochondrial membrane entities and also elicit the positive change in mitochondrial membrane potential responsible for glutathione influx into mitochondria.

In conclusion, we showed that red ginseng could be effective in normalizing the metabolism of ethanol under short-term ethanol ingestion in rats, but it did not constrain an increase in serum $\gamma$-GT activity induced by long-term ethanol intake. Our studies suggest that in the context of chronic ethanol ingestion, red ginseng does not seem to sufficiently restore the physiological response to the status quo ante, in a view of serum biomarker, $\gamma$-GT activity.

\section{REFERENCES}

1. Attele AS, Wu JA, Yuan CS. Ginseng pharmacology: multiple constituents and multiple actions. Biochem Phar- macol 1999;58:1685-1693.

2. Vogler BK, Pittler MH, Ernst E. The efficacy of ginseng. A systematic review of randomised clinical trials. Eur J Clin Pharmacol 1999;55:567-575.

3. Sung HS. Present and future on the processing of ginseng. Korean J Ginseng Sci 1986;10:218-232.

4. Kitagawa I, Taniyama T, Shibuya H, Noda T, Yoshikawa M. Chemical studies on crude drug processing. V. On the constituents of ginseng radix rubra (2): comparison of the constituents of white ginseng and red ginseng prepared from the same Panax ginseng root. Yakugaku Zasshi 1987; 107:495-505.

5. Kim JH. Cardiovascular diseases and Panax ginseng: a review on molecular mechanisms and medical applications. J Ginseng Res 2012;36:16-26.

6. Song JY, Akhalaia M, Platonov A, Kim HD, Jung IS, Han YS, Yun YS. Effects of polysaccharide ginsan from Panax ginseng on liver function. Arch Pharm Res 2004;27:531538 .

7. Kaneko H, Nakanishi K. Proof of the mysterious efficacy of ginseng: basic and clinical trials: clinical effects of medical ginseng, Korean red ginseng: specifically, its anti-stress action for prevention of disease. J Pharmacol Sci 2004;95:158-162.

8. Walsh K, Alexander G. Alcoholic liver disease. Postgrad Med J 2000;76:280-286.

9. Gramenzi A, Caputo F, Biselli M, Kuria F, Loggi E, Andreone P, Bernardi M. Alcoholic liver disease: pathophysiological aspects and risk factors. Aliment Pharmacol Ther 2006;24:1151-1161.

10. Lieber CS. Biochemical and molecular basis of alcoholinduced injury to liver and other tissues. N Engl J Med 1988;319:1639-1650.

11. Purohit V, Gao B, Song BJ. Molecular mechanisms of alcoholic fatty liver. Alcohol Clin Exp Res 2009;33:191205.

12. Das SK, Nayak P, Vasudevan DM. Biochemical markers for alcohol consumption. Indian J Clin Biochem 2003;18:111-118.

13. Kook S, Han HK, Kim GH, Choi K. The anti-hepatotoxic effect of ginseng in rats: meta-analysis. J Ginseng Res 2008;32:161-170

14. Lee YJ, Pantuck CB, Pantuck EJ. Effect of ginseng on plasma levels of ethanol in the rat. Planta Med 1993;59:17-19.

15. Park HM, Kim SJ, Go HK, Kim GB, Kim SZ, Kim JS, Kang HS. Korean red ginseng prevents ethanol-induced hepatotoxicity in isolated perfused rat liver. Korean J Vet Res 2011;51:159-164.

16. Sturgill MG, Lambert GH. Xenobiotic-induced hepa- 
totoxicity: mechanisms of liver injury and methods of monitoring hepatic function. Clin Chem 1997;43(8 Pt 2):1512-1526.

17. Lynch WJ, Roth ME, Carroll ME. Biological basis of sex differences in drug abuse: preclinical and clinical studies. Psychopharmacology (Berl) 2002;164:121-137.

18. Reeves PG, Nielsen FH, Fahey GC Jr. AIN-93 purified diets for laboratory rodents: final report of the American Institute of Nutrition ad hoc writing committee on the reformulation of the AIN-76A rodent diet. J Nutr 1993;123:1939-1951.

19. Wooles WR. Prevention of the acute ethanol-induced fatty liver by antihistamines and stimulants of hepatic microsomal enzyme activity. Toxicol Appl Pharmacol 1968;12:186-193.

20. Lieber CS, DeCarli LM. Liquid diet technique of ethanol administration: 1989 update. Alcohol Alcohol 1989;24:197-211.

21. Kwak YS, Kyung JS, Kim JS, Cho JY, Rhee MH. Antihyperlipidemic effects of red ginseng acidic polysaccharide from Korean red ginseng. Biol Pharm Bull 2010;33:468-472.

22. Yagi K. Lipid peroxides and human diseases. Chem Phys Lipids 1987;45:337-351.

23. Folch J, Lees M, Sloane-Stanley GH. A simple method for the isolation and purification of total lipides from animal tissues. J Biol Chem 1957;226:497-509.

24. Carr TP, Andresen CJ, Rudel LL. Enzymatic determination of triglyceride, free cholesterol, and total cholesterol in tissue lipid extracts. Clin Biochem 1993;26:39-42.

25. Freund RJ, Wilson WJ. Statistical methods. San Diego: Academic Press, 1997.

26. Baldi E, Burra P, Plebani M, Salvagnini M. Serum malondialdehyde and mitochondrial aspartate aminotransferase activity as markers of chronic alcohol intake and alcoholic liver disease. Ital J Gastroenterol 1993;25:429432.

27. Goldberg DM, Watts C. Serum enzyme changes as evidence of liver reaction to oral alcohol. Gastroenterology 1965;49:256-261.

28. Lee DH, Blomhoff R, Jacobs DR Jr. Is serum gamma glutamyltransferase a marker of oxidative stress? Free Radic Res 2004;38:535-539.

29. Cederbaum AI, Lu Y, Wu D. Role of oxidative stress in alcohol-induced liver injury. Arch Toxicol 2009;83:519548 .
30. Whitfield JB. Gamma glutamyl transferase. Crit Rev Clin Lab Sci 2001;38:263-355.

31. Teschke R, Neuefeind M, Nishimura M, Strohmeyer G. Hepatic gamma-glutamyltransferase activity in alcoholic fatty liver: comparison with other liver enzymes in man and rats. Gut 1983;24:625-630.

32. Shaw S, Rubin KP, Lieber CS. Depressed hepatic glutathione and increased diene conjugates in alcoholic liver disease. Evidence of lipid peroxidation. Dig Dis Sci 1983;28:585-589.

33. Yuan HD, Kim JT, Kim SH, Chung SH. Ginseng and diabetes: the evidences from in vitro, animal and human studies. J Ginseng Res 2012;36:27-39.

34. Kim YK, Guo Q, Packer L. Free radical scavenging activity of red ginseng aqueous extracts. Toxicology 2002;172:149-156.

35. Videla LA, Valenzuela A. Alcohol ingestion, liver glutathione and lipoperoxidation: metabolic interrelations and pathological implications. Life Sci 1982;31:2395-2407.

36. Kera Y, Kiriyama T, Komura S. Conjugation of acetaldehyde with cysteinylglycine, the first metabolite in glutathione breakdown by gamma-glutamyltranspeptidase. Agents Actions 1985;17:48-52.

37. Molina MF, Sanchez-Reus I, Iglesias I, Benedi J. Quercetin, a flavonoid antioxidant, prevents and protects against ethanol-induced oxidative stress in mouse liver. Biol Pharm Bull 2003;26:1398-1402.

38. Devipriya N, Srinivasan M, Sudheer AR, Menon VP. Effect of ellagic acid, a natural polyphenol, on alcoholinduced prooxidant and antioxidant imbalance: a drug dose dependent study. Singapore Med J 2007;48:311-318.

39. Fernandez-Checa JC, Kaplowitz N. Hepatic mitochondrial glutathione: transport and role in disease and toxicity. Toxicol Appl Pharmacol 2005;204:263-273.

40. Park HM, Kim SJ, Mun AR, Go HK, Kim GB, Kim SZ, Jang SI, Lee SJ, Kim JS, Kang HS. Korean red ginseng and its primary ginsenosides inhibit ethanol-induced oxidative injury by suppression of the MAPK pathway in TIB-73 cells. J Ethnopharmacol 2012;141:1071-1076.

41. Kim JW, Lee HB, Joo CN. Uptake of Korean ginseng saponin by rat hepatic mitochondria in vitro. Korean Biochem J 1983;16:142-150. 